\title{
Costs, Prices and Results' Management: A Study Conducted in Fruit Canning Companies Located in Rio Grande do Sul State, Brazil
}

\author{
Alexandre Vieira Braga \\ Universidade Federal de Pelotas, Brazil \\ Universidade do Rio dos Sinos, Brazil \\ E-mail: axvb@hotmail.com
}

Marcos Antônio Souza

Universidade do Vale do Rio dos Sinos, Brazil

E-mail: marcosas@unisinos.br

Clóvis Kronbauer

Universidade do Vale do Rio dos Sinos, Brazil

E-mail: clovisk@unisinos.br

Daniele Gonçalves Braga

Universidade Federal de Santa Maria, Brazil

E-mail: danieleredes@hotmail.com

Received: December 28, 2011

doi:10.5539/ibr.v5n3p58
Accepted: February 1, 2012

Published: March 1, 2012

URL: http://dx.doi.org/10.5539/ibr.v5n3p58

\begin{abstract}
This study aims to examine issues related to the management of inventory, working capital, pricing process and costs in companies operating in the fruit canning segment in the Brazilian state of Rio Grande do Sul. The researched management practices have often been addressed in literature as instruments for achieving greater business efficiency and effectiveness. This empirical study was carried out in 2009 with the eight largest fruit canning companies domiciled in Rio Grande do Sul, those having annual revenues of more than R $\$ 12$ million. Structured interviews were conducted with the financial managers of the studied companies. Data analysis involved the use of descriptive statistical and correlation techniques between variables. The principal results suggest that: (a) most companies form the stocks of inputs for short-term periods, given the limitations of working capital and debt; (b) most of them use cost system or some form of cost structure, employing traditional techniques for measuring and managing production costs; (c) mark-up, applied to total production cost, is the preferred method for calculating sale prices; (d) the most significant and relevant correlations were observed between the costing methods used and the adoption of the marginal contribution concept, as well as between costing methods and the break-even point technique; (e) many conceptual inconsistencies were identified in the responses, suggesting weaknesses in the professional preparation of those interviewed.
\end{abstract}

Keywords: Cost management, Price formation, Financial management

\section{Introduction}

In an economic background of fierce competition, companies increasingly have to seek new ways to run their activities and manage their resources, aiming to reduce costs, increase productivity and meet the requirements of customers at the same time. In this case, the term cost is treated broadly, ie, beyond the traditional production operating costs, those expenditures classified as operating and financial expenses are also considered. As a result, the maintenance of operational assets, including stocks, reflects the use of resources and the generation of financial costs. 
In this context, an example is given by Gomez-Bezares (1999). It is the inventory management, given that by optimizing the use of this investment, it rationalizes the use of available resources in the company. On this same issue, Dias (1987) says that the company must minimize the capital invested in stocks, because it is a major cost generator, ie, its steady increase raises the incidence of financial costs at the same proportion. However, it is impossible for a company to act without stocks at the right time, because the lack of stocks compromises to achieving sales. Dias (1987) adds that it is this complexity that requires the adoption of appropriate management techniques and activities.

According to Martins (2003), the activity of controlling is inserted in this issue, since it enables the planning of resources, the knowledge on costs, verification whether costs are consistent with the plan and, based on the analysis of possible deviations, the direction of course correction actions. Martins (2003) also highlights that, even being the most complete and sophisticated, no cost control system is able to achieve its goals if it cannot count on the full commitment of the company, starting with its top leaders.

Another relevant aspect refers to the results' formation and management. For Perez Jr., Oliveira and Costa (2008), the prices need to consider factors outside the company, but cannot ignore the internal costs, because this comparison allows appropriate decisions about the appropriateness or not of practicing market prices, and direct actions that leverage to achieve greater internal efficiency. In fact, ignoring these aspects of management can undermine the profitability and, consequently, the continuity of business.

The brief background presented till here, applied to companies in general, applies especially to the reality of group of companies selected for this study, ie, the canning industry based in the canning center, of the region of Pelotas, in Rio Grande do Sul State, Brazil.

The study of Madail and Raseira (2008) clarifies that this industry segment emerged at the end of the nineteenth century and was consolidated in the 1970s, when there was the installation of large corporations. In the 1980s, it was possible to witness the closure of many industries in the sector, according to the so-called systemic crisis that hit it. However, as Madail and Raseira (2008) add, yet in the following decade, the companies that remained were consolidated in the market, and from the 40 industries from previous decade only 12, in 2007, reached an important milestone in the business productivity and are now responsible for $98 \%$ of the production of peach compote in Brazil.

Some companies in the industry restructured, increased its industrial park and adopted organizational changes in a similar move to that seen in different branches of production, while others have combined old and new processes. The closure of companies in the industry at the time of crisis, caused a severe unemployment in the region of Pelotas, Rio Grande do Sul, but also served as a challenge to managers for the restructuring and modernization of management practices (Badejo \& Callegaro, 2001).

This is as relevant as the constant threat posed by the entry of foreign products, particularly in Argentina. In this regard, Santos (2009, p.18, our translation) points out that "The imported box with 24 cans sells for $\$ 15$, which represents $\mathrm{R} \$ 1.12$ a unit, considering the dollar at $\mathrm{R} \$ 1.80$. But, in Brazil, the industries need to sell the can at least $\mathrm{R} \$ 2.00$ to cover the cost of production".

Considering the presented context and the industry chosen for this research, the objective is to identify and analyze how the candy canning industries are managing their costs, their inventories and their selling prices. As noted earlier in this introduction, cost is treated broadly, including the ones resulting from practices of working capital management, especially inventories.

Besides this introduction, the study presents a brief theoretical framework on the subject, followed by the presentation of the methodological aspects of research. Then, there is the presentation and analysis of data, followed by conclusions and references.

\section{Theoretical Framework}

\subsection{Sale Pricing Formation}

According to Sardinha (1995) the price can be defined as the amount of money the customer pays to purchase a product, and that the company receives in exchange for the same assignment. From this definition, one can say that price is the monetary value paid by the consumer in order to satisfy their needs, while the supplier receives it with the expected profit from the transaction.

Horngren, Foster and Datar (2000) address another aspect in this regard, arguing that the price of a product or service depends on the supply and demand. They add that there are three major influences that affect pricing decisions: customers, competitors and costs. Customers influence on price formation, as they analyze the amount charged for the goods or service and the benefits that may have got from it, compared to alternative acquisition market. The competitors have reactions to prices charged by other companies and may force them to reduce them in an attempt to 
remain competitive. The prices are fixed hoping to recover costs and generate profit; this way, the study of costs' behavior provides an understanding of their influence on prices and the resulting impacts from the combinations of product prices and volume of sales.

Kotler and Armstrong (1993), in a context of market analysis, emphasize that it is the consumer who will decide if the price of a product is correct after all. In any case, the best is not to charge lower prices, but differentiate the product offered, so it is worth a higher price. Bruni and Famá (2002) present four elements classified as the main objectives in the pricing: (1) provide the highest possible profit in long term, (2) allow the profitable maximization of market share, (3) maximize the productive capacities, avoiding idleness and operating waste, (4) maximize the capital employed to perpetuate the business in a self-sustained way. It is in this approach of maximizing the capital employed that is inserted the focus of this study regarding the working capital and financial costs management.

In an understanding that seeks to combine the strength of the market with business objectives, Sardinha (1995) says that in short term, the price charged for the sale of goods or provision of a service can be influenced by the market, but the survival of a company in the long term, depends on its decisions on consistent policies of pricing and cost management. Thus, prices should consider the company's production capacity, because low prices tend to increase sales, which may cause problems regarding the quality of assistance and delivery. On the other hand, high prices may reduce sales, leading to idleness of productive and personnel structure, ie, in the operational idleness and waste.

Bruni and Famá (2002) emphasize that the capital return is given by profits derived over time. Thus, only through the capacity of cost management and fixed pricing of sale, which is accepted by the market and will generate profits, it is possible to ensure an adequate return on the investment made.

According to Santos (2005), the methods of pricing are: cost-based method, competition-based method; market-based method, and the mixed method.

The cost-based method is the most traditional and most common in the business world. This method usually employs the following elements: total cost, processing cost, marginal cost, required rate of return on capital employed and standard cost. If the used basis is the total cost, it must be applied a desired profit margin on total costs of products. If using variable costs and expenses, the added margin should be sufficient to cover fixed costs and expenses, besides desired profits. This process of considering a fixed margin to a based cost is known as mark-up.

The second pricing methodology uses the competition analysis. On this methodology, Bruni and Famá (2002) state that companies pay little attention to its costs or its demand-competition is what determines the prices to be charged. There may be offer prices-when the company charges more or less than the competition, or proposal-when the firm sets its price, according to its trial, on how competitors will set their price.

For the third method, the price based on market characteristics, the price is established based on the product's perceived value by the market. As stressed by Zuccoloto and Colodeti Filho (2008), this method requires deep knowledge of the market by the company, because it will drive the adoption of correct market actions and ideals for the company facing the battle imposed by competitors. Therefore, knowledge of the market can decide whether the product will be sold at a higher price, attracting higher economic classes, or a popular price, given the layers of lower purchasing power.

The fourth and final approach, the mixed method, is a combination of the three factors discussed in the earlier presented methods: cost, competition and market. Bruni and Famá (2002) point out that this pricing method should be able to consider the quality of the product in relation to consumer needs, the existence of substitute products at more competitive prices, the expected demand of the product, the product market area, price controls imposed by the government, the levels of production and sales that are intended or can be operated, and the costs and expenses to produce, manage and sell the product.

\subsection{Inventory Management}

According to Assaf Neto (2003), the stocks can be divided into four types: (1) goods and finished products, (2) work in process, (3) raw materials and packaging, (4) materials for consumption and warehouses.

Each of these types of stocks has its own importance for companies to invest in its maintenance. Scherr (1989, p.281-282) lists the main reasons for the first three types of stocks above:

a) The maintenance of stocks of goods and finished products means to provide immediate service to customers of the company, seeking to meet a higher level of customer satisfaction by making products available for immediate delivery

b) The maintenance of work in process is motivated by providing a flexible reserve for companies, reducing the dependence of the phases of the production flow. 
c) The maintenance of stocks of raw materials and packaging makes it easy to schedule production, prevents the acquisition of items in times of high prices and represents a protection against the deficiencies of the offer.

In relation to inventory maintenance of consumables and warehouses, Assaf Neto (2003) mentions that the volume of investment in such stock varies depending on the basic characteristics and operational and administrative peculiarities of each company. On the other hand, according to Rogers, Ribeiro and Rogers (2004), the financial manager should not consider these approaches of maintenance of stocks as the only possible ones to solve the listed problems. For instance, the authors suggest alternative strategies that aim to avoid the risk of price fluctuation of raw materials, in which the company may carry out long-term contracts with suppliers, which will specify the prices to be paid and the quantities to be delivered or, in order to stabilize the demand, the company may grant discounts.

It must be highlighted that the management of inventories in the canning sector has special contours given the perishability and seasonality of the main raw material, ie, the fruits. In fact, the non-availability of fruit production throughout the year and useful short-term for its use give rise to the need for more accurate planning and techniques, as well as investment in special storage structure.

\subsection{Concepts and Practices Related to Cost Management}

According to Horngreen (1978), the terminology of costs should be thought as measure in the conventional accounting sense, ie, the amount paid for goods and/or services. In management accounting, different measurement bases can be used as a unit. In addition, the unit is not necessarily always related to a physical product. The figure of the cost object, as emphasized by Hansen and Mowen (2001) makes it easily definable that there are funding entities that best fit due to the need and purpose of the funding.

As Kaplan and Cooper (1998) affirm, for the manufacture of any product, the company is required to make a number of expenses related to items such as raw materials, workmanship, electricity, rental of warehouses for the company's installation and others. These expenses are denominated production costs or just costs.

According to Souza and Diehl (2009, p.10, our translation) cost "is the part of the expense that goes along with product. It is the portion of the productive effort that is transferred to the product." Therefore, cost is the volunteer expenditure made by a company for the development of its products. There are other volunteer expenditures in the company that do not relate directly to the preparation of products: these are expenses, and can be classified according to their nature, in administrative, business or financial expenses. Besides the costs, expenses, there are volunteer expenditures for the purchase of properties or for investments, which are registered in the fixed assets.

Costs can also be considered according to several other classifications. For Martins (2003), direct costs are likely to direct appropriation to the costing objects, by simply having a measure of consumption (kilogram of direct materials consumed, hours of manpower used), so that they can be easily identified and measured with the costing object. As for the indirect costs, on the other hand, are those that are not easily identified with the costing object. Sometimes, because of its non-relevance, some costs are allocated to cost objects through apportionment.

Costs can also be classified as fixed or variable. This traditional classification is approached by Cashin and Polimeni (1982). For them, fixed costs are those that remain unchanged in the total for a period, despite the volume fluctuations or production activity conducted, considered an installed capacity. Variable costs are those that vary directly and proportionally to the volume of activities.

Besides these categories of costs and expenses, within the productive activities of operations and management, there are also those charges arising from the use of active resources in the operations development. They are the financial costs of turnover and permanent investments.

With respect to costing methods, variable costing arose from the need to solve the problems posed by the difficulty of appropriating the indirect fixed costs to products and of great use of the isolated measurement of variable cost.

The variable costing considers the appropriation of all variable costs, direct and indirect, and only variables, to products, given that fixed costs are fully considered to the results of the period-that is, they are structure costs, not products'. In the opinion of Leone (2000), the variable costing is related to the use of costs as supporting factors for making short-term decisions, when the variable costs became relevant, such as the application of the analysis based on the contribution margin and the break-even point. Its rise was due to the recognition of the limitations of absorption costing for management purposes.

Regarding the absorption costing method, Martins (2003) emphasizes that it is the ownership of all production costs for processed goods, ie, all expenses related to the effort of manufacturing are distributed to all produced products.

According to Machado and Souza (2006), some costing methods are more suitable as management tools, others for external reporting, others are more conservative, others more comprehensive, with short or long-term sight. It should 
be taken in mind that there is no method considered the best one to be used indiscriminately, and for all purposes by companies. In fact, depending on the purpose and use of information wanted, there must be chosen one or more than one method concomitantly. So is that other methods, such as activity-based-ABC, or unit production effort UEP (Souza \& Diehl, 2009) and full, among others, may be privileged in relation to the objectives of costing and usefulness of information to be generated.

Within the bias of the cost planning, the methodology of the target costing, or goal-cost, according to Sakurai (1997), is a strategic process of cost management to reduce total costs in the planning and product design stages. It is useful in the stages of product development, and encourages innovation, focusing the efforts of all sectors of the organization seeking profit set to be achieved through products that meet standards of quality, delivery time and price demanded by the market. The logic behind this method is that the cost is determined by two other variables, ie, the market selling price and the expectation of profit implicit in the planning.

In addition to the established planning target costing there is the standard cost method, aimed at controlling the efficiency of the planned resource consumption in the measurement of the target costing (Sakurai, 1997). Kraemer (1995) presents a historical overview, emphasizing that the standard cost method is of America, which aims to establish measures of comparison (standard) determined from the average or theoretical production history, or even through pilot production. Patterns are established in the production process from a normal work situation to be achieved within efficient operating conditions. A more contemporary view on the planning and cost control brings an understanding of integration between the target costing and standard costing, the latter being prepared based on the goals established by the first. The comparison between the actual cost and standard cost reflects the occurred cost variations, which must be analyzed in order to correct the causes that originated them, being such variations favorable, are unfavorable.

\subsection{Management of Working Capital}

The term working capital is concerned to short-term assets of the company, such as inventory, receivable accounts, as well as their short-term liabilities, debts to suppliers representative, taxes and miscellaneous charges etc. The management of working capital is a daily activity that aims to ensure that the company has sufficient resources to continue operations and avoid expensive disruptions.

Teló (2001) mentions that close examining each of the items of working capital on an ongoing basis is a priority for the administrator. The most commonly used instrument within organizations to manage the working capital is cash flow, both strategically, when it supports decision-making, and tactically, when connected to restricted horizon.

It must be noted, in the context of working capital, the relevance of the management of loans given to customers on credit sales, of the stocks in its many forms and of purchasing policies adopted in relationships with suppliers. On these issues, there is vast literature dealing with the management practices of these key elements of working capital, such as Assaf Neto (2003), Gitman (2001), Brigham, Gapenski and Ehrhardt (2001), Jaffe, Westerfield and Ross (2002). In all of these elements, which has currently been a challenge for managers is to adopt practices that have in the proper temporal sizing a relevant aspect.

So, getting the value of sales in the shortest possible time, making purchases with longer and equalized period with the sales, and maintaining the lowest inventory level, optimizing its rotation without affecting the production flow. The practice of just-in-time is an example of these practices. The search for the balance of these operating terms is, within the financial management, as its more transparent result the balance, or imbalance, of cash flow, impacting in greater or lesser dimension of financial costs of fundraising. In theory, the lower the efficiency of the management of working capital, the greater the need for additional resources and its financial costs.

Thus, given that investments are made to sustain the implementation of activities in the company, it is logical to conclude that inefficiencies in the process of resource consumption (cost of production beyond the planned, unnecessary inventory maintenance, loss of sale due to the market with unrealistic prices, incorrect decisions on acceptance or not of special requests etc.) lead to the need to resort to sources of working capital (of its own or from others), resulting in additional financial costs, whether as interest or dividends.

\section{Methodological Procedures}

Based on the definitions established by Gil (1999), this research has exploratory and descriptive characteristics. The exploratory aspects are present in order that the study aims to increase knowledge about the pricing and costs in the companies surveyed. The descriptive characteristics are revealed in the description of the degree of awareness of company managers about the use made of the practices surveyed. 
Also according to Gil (1999), as to the means, it is a field research whose data were collected in places where the events occur, ie, in the small and medium industries, located in the city of Pelotas and surrounded ares, in the state of Rio Grande do Sul.

Finally, as to the approach and data analysis, and based on Raupp and Beuren (2003), the study presents qualitative and quantitative characteristics. By performing a preliminary analysis of responses to the questions formulated, we use the qualitative approach. Further, by assigning numerical values to answers and trying to identify statistically significant correlations between them, we use a quantitative approach of analysis.

The research consists of 13 canning industries, small and medium ones, based in Rio Grande do Sul, registered in Sindicato das Indústrias de Conservas de Pelotas e Região, according to registers published in 2009. These companies primarily develop activities of peach, fig, plum and pineapple in syrup industrialization.

The criterion for defining the sample was the declared value of annual revenues, informed by Sindicato das Indústrias de Conservas de Pelotas e Região. It was established a limit of R 12 million in 2009; it was found that from the ninth company, in order of billing, this indicator is markedly reduced, showing companies far smaller than others, which characterizes lack of homogeneities in the sample, hindering comparative analysis. Thus we adopted the intentional criterion because it was surveyed a sample of eight companies belonging to the identified sector. The eight participating companies represent approximately $82 \%$ of total revenues in the sector in the surveyed area.

Data collection was due to the use of structured interviews, conducted with managers of financial firms.

For data analysis, first we present the answers to the questions made. The responses were interpreted, allowing a qualitative analysis of this information with the managers of the surveyed companies.

Then, in order to enable more significant results, it was measured the degree of correlation between selected variables, to identify, from the definition of Stevenson (1981), the extent to which responses are related to each other, which allows to infer whether there is consistency in them.

To carry out this analysis, qualitative variables (responses) were transformed into quantitative variables, using for this purpose, the feature of creating dummy variables. The dummy variables are binary ones that can assume only 0 or 1 values, and thus can be correlated or be included in models. The software used in the correlation analysis was MS Excel.

\section{Data Analysis and Presentation}

\subsection{Interpretation and Qualitative Analysis of Responses}

This section presents the answers to the questions, followed by a brief analysis and interpretation. To provide better understanding for the reader, it presents the asked question, and then the respective analysis.

\subsubsection{If the Company is an Exporter or Recently Performed Exportation (within Three Years)}

Although the survey sought to identify the purchasing, cost and price management, it was considered necessary to identify the companies transactions with the foreign market, as this enables better identification of the competitive environment that the company is exposed to. It was identified by the responses, that $50 \%$ of firms are exporters or made exports in the last three years, but those with non-representative values.

\subsubsection{Managers' Level of Instruction}

On this issue, we sought to identify the area of knowledge in which managers had their training. It was found that from the eight respondents, five have graduate in the economics field (economics / accounting / management). The others did not have higher education or their graduation had not happened so far.

From the responses, it is clear that most managers are trained in the area of economics, although it was desirable that all managers have instruction in this area. It is appropriate in the course of this study to check for any influence of graduation in management and control ways adopted in the companies.

\subsubsection{Experience of the Manager in His/Her Actual Position}

Seeking to identify the experience of the manager in his function, it was observed that, except for one respondent, all others reported having more than ten years of experience in the management position, which shows good knowledge to perform their activities. Experience, coupled with a good academic background are important factors for successful management.

\subsubsection{Strategy Adopted for the Purchasing Moment}

Five of the eight respondents indicated that the purchases are made when there is immediate need of supplies, the other three respondents stated that carry purchases when the price is at lower levels, regardless the existence or not of immediate need. 
Interpreting the answers, we find that approximately $63 \%$ of respondents make purchases when there is immediate need for inputs. This behavior is in accordance with the best practice management of working capital invested in inventory. However, it is necessary to examine whether this behavior is related to the level of capitalization of companies, situation to be assessed in the following section.

\subsubsection{Policies for Maintaining Stocks}

This question aimed to assess the medium-term storage practiced. The findings revealed that managers in five companies hold stocks only to meet the demands of short-term (up to one year/season). Other responses indicate that the volume of maintained inventories aims to meet the demands of short and medium term (1-2 years/season).

The obtained responses seem consistent with those obtained in the previous question, because the same $63 \%$ of respondents indicated that inventories are maintained to meet short term demands. This response is consistent with the percentage number of companies that declared to buy their inputs only when there is need for them.

\subsubsection{Costing Method Adopted for Decision Making}

This question sought to identify the costing method used by companies. It was found that from the eight surveyed companies, five use absorption costing to make their decisions, while the other three respondents make use of variable costing.

It can be observed that most companies make decisions based on the total costs absorbed by the products in the production process. This reveals that these firms prioritize the vision of all the costs absorbed by the products at the time of decision making. Here it can be noticed an inconsistency in relation to the literature in the area, which emphasizes the limitations of the information generated by the absorption costing method when used for management purposes.

\subsubsection{Criteria for Sale Price Formation}

Managers were asked about the criteria used for the formation of sale prices. It was observed that six companies make use of the mark-up on total production costs to calculate the selling price; other two companies form the sale price according to the market average.

Interpreting the answers, we find consistency with the previous answers, because companies tend to use as a basis for formulating their sales prices, the total costs of production, which is related to costing by absorption. Still, it must be checked if correlation between these issues exists-that will occur in the next section.

\subsubsection{Using the Contribution Margin Concept}

In order to identify the use of the concept of contribution margin in management, it was observed that three companies accounted for using the concept of decision making, while five companies responded not to use this technique.

By analyzing the responses, there is a minority of companies (37\%) that use the concept of contribution margin. The answers are consistent with the costing method adopted by companies, because as the answer to question 7 , three companies revealed using variable costing, which best fits to the concept of contribution margin.

\subsubsection{Calculation of the Break-Even Point (by Product, Product Line or Total)}

This question wanted to get information on the calculation of the break-even point in companies. The findings revealed that all managers calculate the total break-even point in the company and not by product. It is noticed that the surveyed companies seek to strike the global break-even point, even if it means smaller gains or losses in some sectors or products.

\subsubsection{Method of Calculating the Break-Even Point}

This issue served as a validation of the previous question, obtaining two different types of responses. Three companies responded to calculate the sum of fixed costs and expenses, to divide this sum by the weighted average of contribution margin. The other five companies calculate it by subtracting the total disembeddings of total revenues, in a given period of time.

Analyzing the answers to this question, and comparing them with of previous ones, there is a conceptual mistake in most companies ( $63 \%$ ) because subtracting the total disembeddings of total revenues is more like a flow of resources in cash basis than the proper break-even point.

This is corroborated by evidence arising from the question eight, at which time three companies responded using the concept of contribution margin for decision making, and five companies responded did not use the contribution margin. 


\subsubsection{Calculation of Profitability (by Product or Product Family)}

The purpose here was to see whether companies calculate their individual profitability by product or product family. It was observed that the number of companies that calculate profitability by product is equal to the number of those who calculate it by product family.

When answering this question, there is a contradictory aspect. It is consistent that companies choose to calculate their profitability by product or segment, but these responses do not support what was said in the 9th question, as for those respondents who showed how to calculate the total break-even point of the company.

\subsubsection{Use of Standard Cost and Target / Goal Cost}

This question sought information on the use of standard cost or target cost. Five companies responded to use standards for monitoring and testing of production (product launches) and cost range goals when the actual process of production. The other three participant companies answered to use only the standard cost for monitoring.

By the answers, we find again some conceptual inconsistency, particularly with regard to the term used by respondents, that is, patterns of costs and not standard cost. So even if managers have mostly revealed having academic instructions in the field of economics, one cannot affirm that they understand the differences of the concepts in the standard cost and target cost.

\subsubsection{Proportion of Companies' Own Capital and Third-Party's Used (Leverage)}

To this question, different answers were obtained, summarized in Table 2, identifying the proportion of companies' own capital used. As requested by companies, their identities were hidden.

Analyzing data in Table 2, we find that the majority of respondents (five) reported that the company has a significantly financial structure leveraged by third-party resources, since their own resources represent between $30 \%$ and $50 \%$ of their capital sources.

\subsubsection{Implementation of Partnerships with Customers, Suppliers and Competitors}

The goal was to identify whether the company has partnerships with customers, suppliers or competitors. It is observed by all given answers that companies develop some kind of partnership with customers and suppliers, but no kind of partnership with their competitors.

Since these responses were not included in the framework of correlation analysis, it was considered advisable to analyze the responses obtained in this part of the research. By the answers, all companies reported having some kind of partnership with customers and suppliers, and no partnership with competitors, which may be evidence of the fierce competition in the sector and lack of benefits of a joint action between them.

Chiamulera (2002, p.2, our translation) comments that "since we started in business we are prepared to 'hate' our competitors, wanting to see them defeated". The corporate world today seems to be awakening to a management practice which, although not new, it is still rarely practiced. It is known as operating agreements, among other names, partnerships, cooperation networks or agreements for technology transfer, and is conducted between companies that have always been fierce competitors. A practice that is becoming common in the market are cooperation agreements of non-competitors, but that have common needs. It is common, as referred Olave and Amato Neto (2007), that companies join together to launch shopping portals on the Internet and thereby reduce the acquisition costs of raw materials for their operations.

This can be a factor to be fostered in the surveyed companies, which could seek to implement this practice in the industry for mutual benefit of growth.

\subsection{Analysis of Significant Correlations in the Responses of Managers}

To evaluate possible relationships between the responses obtained in the research (or the lack of them), we prepared Table 2, shown bellow.

Before interpreting data in Table 2, it is noteworthy that the correlation coefficients considered statistically significant were those above $70 \%$, a level which is commonly adopted in terms of statistical significance. The analysis of the coefficients is held on topics.

\subsubsection{Exporting Company}

The responses showed that $50 \%$ of firms are exporters. This revealed no significant correlation with the other answers. The highest correlation coefficient (0.5774) is related to the criterion of sale price formation, which does not keep great consistency because considering that export prices are also calculated from the total cost does not reflect the 
competitiveness of the international market. Furthermore, the degree of correlation cannot be considered very relevant.

\subsubsection{Instruction of Managers in the Area of Economics}

The findings revealed that most managers (five of eight) have academic instruction in the economics field. The answers to this question revealed correlation of $100 \%$ (coefficient of 1.0000) with the purchasing strategy, ie, managers with training in the area declared to buy when necessary while those without higher education or training in other areas revealed purchasing when prices are lower. This degree of correlation is consistent and shows the practical adoption of the formative concepts in purchasing management, emphasized by literature.

It is also noticeable significant correlation ( 0.7746 or $77.46 \%$ ) between the managers' instruction and the inventory maintenance strategy, which indicates that managers from the area of economics tend to hold stocks according to short-term demands, which is consistent with the concepts domain of short-term financial management that emphasizes maintaining the lowest possible inventory.

Another significant correlation, but a negative sign, ie, -0.7746 , can be observed between instruction and use of companies' own resources to finance the enterprise turnover. Thus, managers with study in economics revealed to work with greater leverage, ie, the lowest percentage of own resources. The consistency or not of this degree of correlation depends on another factor not analyzed in this study-the interest rate. Literature has shown that the smaller it is, the greater the potential benefits of using third party resources.

To conclude, it is noteworthy that there is no significant correlation between the instruction of managers and issues related to criteria of the sale price formation, calculation of profitability and use of standard cost and target cost. This lack of correlation confirms what has already been reviewed in the analysis of questions 10, 11 and 12 of section 4.1, revealing a conceptual inconsistency between the instruction of managers and the adoption of management tools in practice. It is shown here an opportunity to conduct researches in greater depth to clarify these issues.

\subsubsection{Manager Experience in the Present Function}

It was found that except for one, all other managers held significant experience in their functions. This situation did not reveal very significant correlation with the other responses, although there are correlation coefficients of 0.6000 $(60 \%)$ with the method of costing for decision making, use of contribution margin and break-even calculation method. It should be noted that these coefficients do not hold great significance in terms of conceptual relationship, because there is no significant correlation between managers' instruction and experience. Apparently, the managers' instruction has not led them to the use of useful management practices recognized in the literature.

\subsubsection{Strategy Adopted for the Moment of Purchasing}

When answering to this question, five managers revealed that the purchases are made when there is immediate need of inputs, while the other three respondents said they carry out purchases when the price is at lower levels.

The answers to this question revealed a correlation of $77.46 \%$ (coefficient of 0.7746 ) with the inventory management strategy, which means that most managers who buy stocks when necessary, tend to maintain these levels according to the short-term demands, which is consistent with the domain concepts of short-term financial management and the analysis already carried out in section 4.1. However, it was expected that this correlation was higher, even near $100 \%$, which reveals inconsistency in the obtained responses, subject to other researches in greater depth.

Also, from Table 2, the answers to this question reveal a negative coefficient of correlation of $77.46 \%(-0.7746)$, with the proportion of companies' own capital used. This correlation is consistent, because the less capitalized companies tend to make their purchases only when necessary.

\subsubsection{Policies for Inventory Management}

On this issue, five managers revealed that companies maintain inventories to meet short-term demands. This situation did not reveal very significant correlation with the other answers. Even so, we must highlight the negative correlation of $50 \%(-0.5000)$ with the proportion of companies' own capital used by firms. In this case, it should be expected a degree of negative correlation of $100 \%$, because according to Campos, et al (2002), increasing stock reflects in the increase of the NWC (Need for Working Capital), and therefore, in the debt, if there are no own sources of resources.

Therefore the most leveraged companies in their capital tend to fill their inventories of inputs only when needed, in order not to extrapolate its debt; on the other hand, most capitalized companies may be able to buy when in the most propitious moment in terms of costs, obtaining competitive advantage compared to the others.

An inconsistency between the answers and the degree of calculated correlation is noticed, which may prove an inappropriate situation in the inventory levels management of the companies or even a conceptual inconsistency in the managers' perception. 


\subsubsection{Costing Method Used for Decision Making}

Five managers responded using costing by absorption to make decisions while the remaining three make use of variable costing. These responses correlated $100 \%$ (1.0000) using the concept of contribution margin and the criterion used to calculate the break-even point. Thus, all managers that revealed using the absorption costing method, reported that calculate the break-even point improperly, ie, the total revenue minus total disembeddings, while they have proven not to use the concept of margin contribution.

Based on this coefficient, we conclude that the three managers who responded using variable costing, reported that calculate the break-even point by the sum of fixed costs and fixed expenses, to divide this sum by the weighted average contribution margin, while reporting using the concept of contribution margin.

There is consistency with correlation coefficients, although the answers coming from this issue seem conceptually contradictory.

These responses also showed significant correlation (77.46\%) with the adoption of the concepts of standard costing and target costing. Thus, the majority of managers who responded using costing by absorption to make their decisions, revealed that adopt standard costs for monitoring and testing production (product launches) and goals of achieving cost, in the actual process of production. As stated in section 4.1, we find conceptual inconsistency, particularly with regard to the term used by respondents, that is, patterns of costs and not standard cost.

\subsubsection{Criteria for Sale Price Formation}

On this issue, six companies responded to the use mark-up on total production costs to calculate the selling price, while the others said to form the sale price according to the market average. This did not reveal very significant correlation with the other answers. Still, it is necessary to highlight the negative correlation of $57.74 \%(-0.5774)$ with the method of calculating the profitability and the adoption of the concepts of standard costing and target costing.

The low significance of these correlations indicates a conceptual problem, because although it is recognized that the formation of prices through mark-up first aim to price the product internally so that it can be compared with the market, calculating the price is also required and the manager cannot do it by the average market price, without knowing the net margin, evidenced by the pricing process with the mark-up. Using only the market average, the manager can deduce that costs are also market averaged, which may not represent reality, ie, a competitor may be profiting from the sale, at a certain price, and the company having losses to match the sale price.

\subsubsection{Using the Contribution Margin}

It was observed that three managers use the technique of margin contribution to decision making, while five said they did not. These responses correlated $100 \%(1.0000)$ with the criterion adopted to calculate the break-even point and $77.46 \%$ (0.7746) with the adoption of the concepts of standard costing and target costing. Thus, for these three managers, the correlations show conceptual consistency with the cost criteria adopted by them.

\subsubsection{Method of Calculating the Break-Even Point}

The answers revealed that all companies calculate the total break-even point of the company, which shows a correlation of $77.46 \%$ (0.7746) with the adoption of the concepts of standard costing and target costing, ie, most managers revealed adopting these cost concepts.

It should be noted that the method of calculating the break-even point also showed $100 \%$ correlation with the cost method for making decisions and with the usage of the contribution margin, as already discussed in these two items.

Completing the analysis of correlations, as the data shown in Table 2, it is worth noting that the criteria for calculation of profitability is not significantly correlated with any of the other discussed issues. The other significant correlations have been considered in previous sections.

\section{Conclusions and Recommendation}

\subsection{Conclusions}

This study aimed to analyze the cost management process and the pricing of canning industries of Rio Grande do Sul. First, it was observed that most companies have a cost system or some form of cost structure and analysis of the break-even point. It was found that the main criterion used in the sale price process is the mark-up, applying it on the cost of production, and that small proportion of companies use only the criterion of the market to set prices.

The results, in spite of these limitations, show that managers adopt practices that may be considered appropriate, regarding the management of inventory, costs and prices. On the other hand, development in these aspects and resolving pointed out inconsistencies, as to the standard cost systematic and break-even point calculation, can lead canning industries to move into a management that use appropriate tools and techniques, as presented in the theoretical 
framework. That is, the procedures adopted by current businesses are distant from the best practices recommended by the literature.

As emphasized in the literature in the theoretical framework, the current stage of marketing competition requires companies to use, more and more, new ways to manage their resources so they can reduce their costs, increase productivity and still meet customers' demands. The historical evolution of the canning segment, with the closure of several companies, indicates that in the past some companies may not have given the proper attention to more appropriate management practices. Such signs of the past can serve as an impetus to change the current reality. The current picture of the threat of Argentine products, presented by Santos (2009), as discussed in the introduction of this study is a reality that cannot be neglected.

\subsection{Recommendations for Further Study}

The inventory management practices, as well as the methods and systems of planning and cost control and the formation of partnerships with competitors are inserted in this context, which indicates a significant potential for further studies. Then, deep studies, perhaps along the lines of single case study, can enable new discoveries on the management of companies in the sector, including addressing the reason for not using best practices addressed in literature. Moreover, it is recommended to proceed even in the historical and cultural aspects that, over time, have directed the formatting of the management model adopted by companies.

\section{References}

Assaf Neto, A. (2003). Finanças corporativas e valor. São Paulo: Atlas.

Badejo, M. S., \& Callegaro, D. (2001). Agregação de valor ao cliente e formação de preço: um estudo da cadeia produtiva de pêssego de Pelotas RS. Anais do III Congresso Internacional de Economia e Gestão de Negócios Agroalimentare, Ribeirão Preto.

Brigham, E. F., Gapenski, L. C., \& Ehrardt, M. C. (2001). Administração financeira. São Paulo: Atlas.

Bruni, A. L., \& Famá, R. (2002). Gestão de custo e formação de preço. São Paulo: Atlas.

Campos, L., Stamford, A., \& Campos, M. (2002). Otimizando a capacidade de crescimento numa cadeia produtiva supermercadista. Revista Produção, 12, 6-17.

Cashin, J. A., \& Polimeni, R. S. (1982). Curso de contabilidade de custos. São Paulo: McGraw-Hill.

Chiamulera, C. (2002). Acordo entre concorrentes traz benefícios para as empresas envolvidas e para o consumidor. Magazine FAE Business, 2, 14-16.

Dias, M. P. (1987). Manual da administração de materiais: planejamento e controle de estoques. São Paulo: Atlas.

Gil, A. C. (1999). Métodos e Técnicas de pesquisa social. São Paulo: Atlas.

Gitman, L. J. (2001). Princípios de administração financeira. Porto Alegre: Bookman.

Gomez-Bezares, F. (1999). Las definiciones financieras en la práctica. Bilbao: Desclée de Brouwer.

Hansen, D. R., \& Mowen, M. M. (2001). Gestão de custos: contabilidade e controle. São Paulo: Pioneira Thomson Learning.

Horngren, C. T. (1978). Contabilidade de custos: um enfoque administrativo (Vol. 1). São Paulo: Atlas.

Horngren, C. T., Foster, G., \& Datar, S. M. (2000). Contabilidade de custos. Rio de Janeiro: LTC.

Jaffe, F. F., Westerfield, R. W., \& Ross, S. A. (2002). Administração financeira. São Paulo: Atlas.

Kaplan, R. S., \& Cooper, R. (1998). Custo e desempenho: administre seus custos para ser mais competitivo. São Paulo: Futura.

Kotler, P., \& Armastrong, G. (1993). Principios de marketing. Rio de Janeiro: Prentice Hall

Kraemer, T. (1995). Discussão de um sistema de custeio adaptado às exigências da nova competição global. Dissertação de Mestrado. Universidade Federal do Rio Grande do Sul - UFRGS, Porto Alegre.

Leone, G. S. G. (2000). Curso de contabilidade de custos (2nd ed.). São Paulo: Atlas.

Machado, D., \& Souza, M. A. (2006). Análise das relações entre a gestão de custos e a gestão do preço de venda: um estudo das práticas adotadas por empresas industriais conserveiras no RS. Revista Universo Contábil, 2(1), $42-60$. 
Madail, J. C. M., \& Raseira, M. C. B. (2008). Aspectos da produção e mercado do pêssego no Brasil. Circular Técnica 80. Acessed in september 30th, 2009, http://www.cpact.embrapa.br/publicacoes/download/circulares/Circular_80.pdf.

Martins, E. (2003). Contabilidade de custos (9th ed.). São Paulo: Atlas.

Olave, M. E. L., \& Amato Neto, J. (2007). Redes de cooperação produtiva: uma estratégia de competitividade e sobrevivência para pequenas e médias empresas. Gestão \& Produção, 8, $289-318$. http://dx.doi.org/10.1590/S0104-530X2001000300006

Perez Jr., J. H., Oliveira, L. M., \& Costa, R. G. (2008). Gestão estratégica de custos (5th ed.). São Paulo: Atlas.

Raupp, F. M., \& Beuren, I. M. (2003). Metodologia de pesquisa aplicável às ciências sociais. In BEUREN, I. M. (Org.). Como elaborar trabalhos monográficos em contabilidade. São Paulo: Atlas.

Rogers, P., Ribeiro, K., \& Rogers, D. (2004). Avaliando o risco na gestão financeira de estoques. Anais do VII Simpósio de Administração da Produção, Logística e Operações Internacionais - SIMPOI, São Paulo.

Sakurai, M. (1997). Gerenciamento integrado de custos. São Paulo: Atlas.

Santos, J. J. (2005). Fundamentos de custos para formação do preço e do lucro (5th ed.). São Paulo: Atlas.

Santos, L. (2009). Concorrência Argentina faz sobrar pêssego no RS. Correio do Povo Newspaper, p. 18.

Sardinha, J. C. (1995). Formação de preço: a arte do negócio. São Paulo: Makron Books.

Scherr, F. C. (1989). Modern working capital management. New York: Prentice-Hall.

Sindicato das indústrias de conservas de Pelotas (2009). O setor de conservas em Pelotas-RS: Relatório de pesquisa. Pelotas: SINDOCOPEL.

Souza, M. A., \& Diehl, C. A. (2009). Gestão de custos: uma abordagem integrada entre contabilidade, engenharia e administração. São Paulo: Atlas.

Stevenson, W. J. (1981) Estatística aplicada à administração. São Paulo: Harper \& Row do Brasil.

Teló, A. (2001). Desempenho organizacional: planejamento financeiro em empresas familiares. Rev. FAE, 4(1), 17-26.

Zuccolloto, R., \& Colodetti, E. (2008). Gerenciamento de preços em empresas de pequeno porte por meio do custeio variável e do método de Monte Carlo. Reflexão Contábil, 26, 39-52.

Table 1. Proportion of Companies’ Own Capital Used in Relation to the Total Turnover

\begin{tabular}{cccc}
\hline Company & Proportion of companies' own capital & Company & Proportion of companies' own capital \\
\hline 1 & $30 \%$ & 5 & $30 \%$ \\
2 & $35 \%$ & 6 & $80 \%$ \\
3 & $100 \%$ & 7 & $40 \%$ \\
4 & $50 \%$ & 8 & $90 \%$ \\
\hline
\end{tabular}


Table 2. Correlations between Managers Answers

\begin{tabular}{|c|c|c|c|c|c|c|c|c|c|c|c|c|}
\hline Item & 1 & 2 & 3 & 4 & 5 & 6 & 7 & 8 & 9 & 10 & 11 & 12 \\
\hline 1 & 1 & & & & & & & & & & & \\
\hline 2 & 0.2582 & 1 & & & & & & & & & & \\
\hline 3 & -0.2582 & 0.4667 & 1 & & & & & & & & & \\
\hline 4 & 0.2582 & 1.0000 & 0.4667 & 1 & & & & & & & & \\
\hline 5 & 0.0000 & 0.7746 & 0.2582 & 0.7746 & 1 & & & & & & & \\
\hline 6 & 0.2582 & 0.6000 & 0.6000 & 0.6000 & 0.2582 & 1 & & & & & & \\
\hline 7 & 0.5774 & 0.1491 & 0.1491 & 0.1491 & 0.0000 & 0.4472 & 1 & & & & & \\
\hline 8 & 0.2582 & 0.6000 & 0.6000 & 0.6000 & 0.2582 & 1.0000 & 0.4472 & 1 & & & & \\
\hline 9 & 0.2582 & 0.6000 & 0.6000 & 0.6000 & 0.2582 & 1.0000 & 0.4472 & 1.0000 & 1 & & & \\
\hline 10 & 0.0000 & -0.2582 & 0.2582 & -0.2582 & -0.5000 & 0.2582 & 0.5774 & 0.2582 & 0.2582 & 1 & & \\
\hline 11 & 0.5000 & 0.2582 & 0.2582 & 0.2582 & 0.0000 & 0.7746 & 0.5774 & 0.7746 & 0.7746 & 0.5000 & 1 & \\
\hline 12 & -0.5000 & -0.7746 & -0.2582 & -0.7746 & -0.5000 & -0.2582 & 0.0000 & -0.2582 & -0.2582 & 0.5000 & 0.0000 & 1 \\
\hline Item & \multicolumn{5}{|c|}{ Description } & Item & \multicolumn{6}{|c|}{ Description } \\
\hline 1 & \multicolumn{5}{|c|}{ Exporting Company } & 7 & \multicolumn{6}{|c|}{ Criteria for Selling Price Formation } \\
\hline 2 & \multicolumn{5}{|c|}{ Managers' Instruction } & 8 & \multicolumn{6}{|c|}{ Usage of Contribution Margin Concept } \\
\hline 3 & \multicolumn{5}{|c|}{ Manager's Experience in Present Function } & 9 & \multicolumn{6}{|c|}{ Break-even Point - Method } \\
\hline 4 & \multicolumn{5}{|c|}{ Purchasing Strategy } & 10 & \multicolumn{6}{|c|}{ Calculation of Profitability (product or family) } \\
\hline 5 & \multicolumn{5}{|c|}{ Inventory Maintenance } & 11 & \multicolumn{6}{|c|}{ Use of Standard Cost / Target Cost } \\
\hline 6 & \multicolumn{5}{|c|}{ Costing Method for Decision Making } & 12 & \multicolumn{6}{|c|}{ Proportion of Company's Own Capital } \\
\hline
\end{tabular}

